\title{
The Behavior of Corona Ions in Corona-Charged Electrophotographic Sensors
}

\author{
Takeaki IIda and Hiroshi NozAKI \\ Institute of Industrial Science, University of Tokyo
}

\begin{abstract}
It is well known that the dark and photo-decay of coronacharged photoconductor-polymer dispersion layers are given experimentally as the Inoue's equation

$$
V(t)=V_{0} \exp (-\alpha \sqrt{t})
$$

and Iida found that the plot between $\log V(t)$ and $\sqrt{t}$ has a linear relation in which the gradient of this linear line is proportional to the square root of the absolute temperature.

There are many explanations and estimations on this coronacharging phenomena. For example, the capacitance and the resistance of the layer change non-linearly with the increase of accumulation of charges in the layer. And, it is also estimated that the surface states of photoconductor change with the temperature and it gives the non-linear effects on the layer's capacitance and resistance. However, it is considered that these assumptions are so complicated that neither the formation of Inoue's equation nor experimental proof will be easily obtained.

So, we considered a model in which corona ions diffuse across the layer along an electrical field after chemisorbing into the layer's surface. Then the differential equations which are derived from the transportation theory of nonequilibrium thermodynamics are calculated. And, the solution of these equations satisfies not only the linearity between $\log V$ and $\sqrt{t}$, but also the linearity of the line gradient against the square root of the absolute temperature. Many experimental results support this solution consistently. Therefore, we inferred that corona ions diffuse into the layer and this difiusion speed determines the rate of the dark decay of coronacharging processes.

In the case of dark decay process, it seems that the charges of the corona ions, which diffuse to the reverse side of the layer, are neutralized by the positive charges, and they are deposited in the air regions of the grain boundary, or excluded to the outside of the layer. However, in the case of photo-decay process, the electrons-and-holes, which are generated by the light irradiation, neutralize the charges of corona ions at the each surface of photoconductor. It is explained that the corona ions are neutralized rapidly without traveling a long distance. The rate is determined by the diffusion speed along the thickness of around $0.1 \mu$, then the corona potential decays rapidly in the case of the photo-decay.
\end{abstract}

7-22-1, Roppongi, Minato-ku, Tokyo 


\title{
コロナ帯電した電子写真センサー におけるコロナイオンの挙動
}

\author{
飯田武揚 - 野 崎弘
}

要 旨

電子写真センサーのコロナ帯電に和ける暗時, および光照射時の電位減衰の速度式は実 験的に井上らの式

$$
V(t)=V_{0} e^{-\alpha \sqrt{t}}
$$

によって与えられ, $\log V(t)$ と $\sqrt{t}$ のプロットを作ると直線になる。この直線の傾斜は 温度の関数で, 温度の高いものほぞ傾斜が大きい。このような実験結果は従来の等仙回 路のモデルからは説明されない。そこでコロナイオンがセンサーに化学吸着した後に拡 散輸送されるといら考光に基づき, 輸送理論の式を使って計算を行なった。その結果, $\log V(t)$ と $\sqrt{t}$ のプロットが直線的になり, その傾斜が温度に依存するという解が得ら れ，いくつかの実験事実をこれによって説明することができた。よって電子写真センサー のコロナ帯電に和ける暗時, 招よび光照射時の電位減衰を律速しているのはコロナイオン のセンサー中での拡散輸送であると考察した。

\section{1. 緒言}

酸化物光電導粉末を高分子で結着させて作られた電子 写真センサーの負コロナ帯電現象は電子写真技術の上で 重要なプロセスであるが, この帯電の機構, 電位の減衰 機構はまだ明らかにされていない。それはコロナ帯電が 主に空気を高電圧でイオン化させて，そのイオンをセン サーに化学吸着させることによっているからであり, 電 位の滅衰はこれらのイオンがセンサ一中からなんらかの 形で消失してゆくことによるからであり, 多くの複雑な 要因を含むからである。一般にコロナ放電は $-5,000$ volt $/ \mathrm{cm}$ ぐらいの電圧で行ない, センサ一上の帯電は -500 volt ぐらいになる。

電子写真センサーの場合, $\mathrm{ZnO}$ あるいは $\mathrm{TiO}_{2}$ などの 光電導粉末と高分子の分散層がコロナイオンをイオン吸 着させる媒体になるので，コロナイオンを吸着する場所 は粉体表面か，高分子表面である。

$\mathrm{n}$ 型半導体表面に負コロナイオンがイオン吸着する場 合, 表面のポテンシャルバリャーは高くなり, センサー

昭和 46.8.13 受理

* 東京大学生産技術研究所

東京都港区六本木 7-22-1
の抵抗はあがる。一方高分子表面に負コロナイオンがイ オン吸着するときには表面にイオンの蓄積層が形成され る。

従来までの電子写真層のコロナ带電は半導体表面のイ オンの脱吸着だけを問題にしてきた。たと党ば 1959 年 に RCA の Amick によってだされたモデル1) $\mathrm{ZnO}$ 表 面のイオンの脱吸着だけを取り上げ，高分子の機能につ いては何もいっていない。このようなモデルではたと兄 ば帯電現象が高分子の種類によって大きく変化すること や，井上らの穾験式）がなぜ成立するのかといらこと や，飯田らの実験結果 ${ }^{3)}$, すなわち温度の高いもの注ど 電位の減衰速度が速いといら事実, らを説明することが できない。

そこでわれわれはコロナ放電によって生じた負コロナ イオンがセンサー中の光電導粉体ならびに高分子のイオ ン吸着中心にイオン吸着して保持され, 保持されたイオ ンは拡散現象といらきわめて速度の遅い形で, センサー の表面から裏面へと輸送されるモデルを考光た。このよ のな考え方でコロナイオンがセンサー中を輸送されてゆ く速度式を輸送理論の関係式から導き出し，その式の正 当性を実験的に確かめ, コロナ帯電現象の電位隇衰過程 に新しい知見を得ることができた。 


\section{2. 理 論}

コロナイオンが層中を拡散してゆくモデルとして図-1

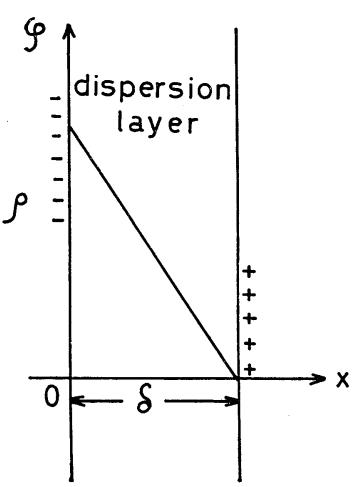

図-1 分散層中のポテンシャ ル分布

に示すように，センサー の表面を $x=0$ にとり， そこに吸着したイオンが 厚さ $\delta$ るつ層中を拡散 輸送されてゆくと考觉る。 コロナイオンはきわめて ゆっくり層中を動いてい くので，系は定常状態を 保って進行するとし，こ の系を非可逆系の熱力学 でいら輸送理論で取り扱 っていく。

コロナイオンの輸送に ついての基本方程式は，(1) 連続の方程式，(2) Fick の拡散の第 1 法則, (3) Poisson の式である。

$$
\frac{\partial \rho}{\partial t}+\boldsymbol{\nabla} \cdot \boldsymbol{J}=0
$$

ここで゚はコロナイオンの電荷でJはその流れである。 $x$ 方向への流机 $J_{x}$ 飞注電界を含む Fick の拡散の第 1 法則を採用する。

$$
J_{x}=R T u \frac{\partial \rho}{\partial x}+F \rho u \frac{\partial \varphi}{\partial x}
$$

ここでRはガス定数, $T$ は絶対温度, $u$ は移動度, $F$ は Faraday 定数, $\varphi$ は層中の電位である。第 1 項はコ ロナイオンの濃度ポテンシャルによる流れで, 第 2 項は 静電ポテンシャルによる流れである。

$\varphi$ については定常状態なら Poisson の式が成立する*。

$$
\frac{\partial^{2} \varphi}{\partial x^{2}}=-\frac{\rho}{\varepsilon}
$$

ここで $\varepsilon は$ 電媒定数である。

式 (2)の $J_{x}$ を式 (1) に入れると,

$$
\frac{\partial \rho}{\partial t}-\frac{\partial}{\partial x}\left(u R T \frac{\partial \rho}{\partial x}+u F \rho \frac{\partial \varphi}{\partial x}\right)=0
$$

この式の $\rho$ を式（3）を使って消去すると

$$
-\varepsilon \frac{\partial^{3} \varphi}{\partial t \partial x^{2}}+\varepsilon u R T \frac{\partial^{4} \varphi}{\partial x^{4}}+\varepsilon \frac{u F}{2} \frac{\partial^{2}}{\partial x^{2}}\left(\frac{\partial \varphi}{\partial x}\right)^{2}=0
$$

* コロナイオンが層中を定常的に動かないときは, Poisson の式は成立しない。そのときは Faraday's law, Gauss' law, Ampere's law から出発して導 き出された

$$
\Delta \varphi+\operatorname{div} \frac{\partial \boldsymbol{A}}{\partial t}=-\frac{\rho}{\varepsilon}
$$

を使う必要がある。これは Poissonの式にベクトル ポテンシャル $\boldsymbol{A}$ の付加項がついている式になって いる。
となる。これを $x$ に関して 2 回積分すると, 次式が得ら れる。

$$
\frac{\partial \varphi}{\partial t}=u R T \frac{\partial^{2} \varphi}{\partial x^{2}}+\frac{u F}{2}\left(\frac{\partial \varphi}{\partial x}\right)^{2}+K_{1} x+K_{2}
$$

問題はこの微分方程式を解くことでせるが，右辺の第 2 項目の静電ポテンシャルによる流れから出てきた項が 非線型微分方程式になっている。そのために通常の方法 では解は得られない。恐らく非線型微分方程式に用いら れる数值解析か差分法を用いなくてはならないだろう。

ここでは式（4）の右辺の第 2 項が比較的小さい系, すなわち静電ポテンシャルによる流れが，濃度ポテンシ ヤルによる流れに比べて比較的小さい系が成立する場合 について解いてみる以外飞方法がない。

そこで式（4）の右辺の第1項を考学てみると，これ は拡散方程式と同様な形をしている。そこで初期条件と

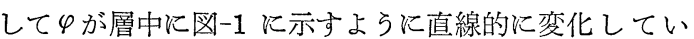
ると近似しよう。すなわち

$$
\varphi(0, x)=\varphi_{0}\left(1-\frac{x}{\delta}\right)
$$

と初期条件をとる。

拡散方程式の解は次式で与兄られる。

$$
\varphi(t, x)=\frac{\varphi_{0}}{2 \sqrt{\pi u R T t}} \int_{0}^{\infty}\left(1-\frac{x}{\delta}\right) \exp \left(-\frac{x^{2}}{4 u R T t}\right) d x
$$

定積分を計算すれば，

$$
\varphi(t, 0)=\frac{\varphi_{0}}{\sqrt{\pi u R T t}}\left(\sqrt{\pi u R T t}-\frac{2 u R T t}{\delta}\right)
$$

変形して

$$
\varphi(t, 0)=\varphi_{0}\left(1-\frac{2 \sqrt{u R T t}}{\delta \sqrt{\pi}}\right)
$$

右辺は Taylor 展開の項に相当すると近似して,

$$
\varphi(t, 0)=\varphi_{0} \exp \left(-\frac{2 \sqrt{u R T t}}{\delta \sqrt{\pi}}\right)
$$

両辺の対数をとれば

$$
\log \varphi(t, 0)=\log \varphi_{0}-\frac{2 \sqrt{u R T t}}{\delta \sqrt{\pi}}
$$

要するに式（7）は電位減衰の対数が時間 $t$ の平方根に 比例し, 比例係数は移動度, 温度, 層の厚さに関係する ものになっている。

\section{3. 実験}

電子写真センサーの作製は特級の $\mathrm{ZnO}, \mathrm{TiO}_{2}$ を气れ ぞれ用い，バインダーとして平均重合度 1400 のポリ酢 酸ビニル（PVAc）を使用した。これらを一定量とり， 陶磁製のボールミルクラッシャーで䣫酸エチルを溶媒と して 10 時間混合させ，その混合液をアルミハク上に平 均 $15 \mu$ の厚さで塗布した。これを $110^{\circ} \mathrm{C} て ゙ 2$ 時間乾燥 


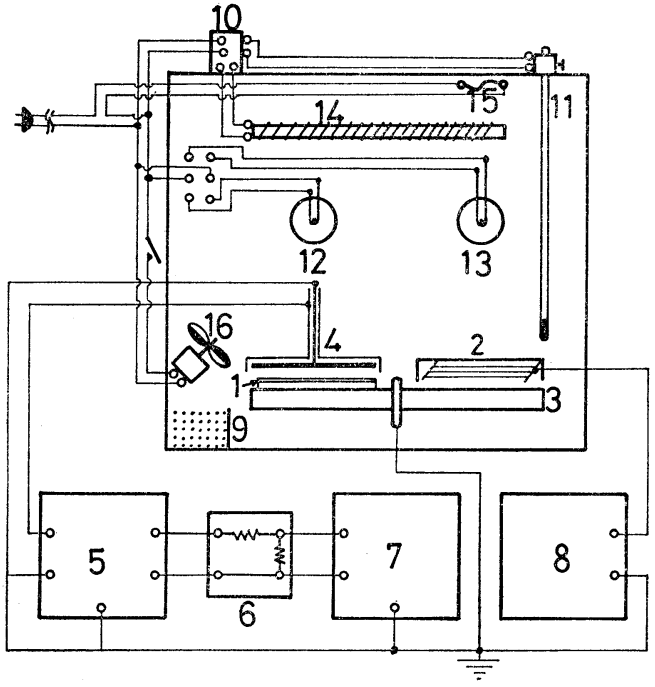

（1）試料，（2）コロナ放電線，（3）ターンテーブル

（4）ディテクター，（5）表面電位計，（6）ディバィ ダー,（7）記録訫，（8）高電圧発生器，（9）シリカ ゲル，（10）リレー，（11）温度リレー，（12），(13） タングステン光源, (14）ヒーター,（15）温度七ュ ーズ, (16) ファン

図-2 コロナ带電電位の測定装置

させて，相対湿度 30\% の暗所に 24 時間以上保持した。

コロナ带電電位の時間変化は図-2 亿示すように温度 と湿度の制御できる室の中で, ターンテーブルを用い, 試料の $5 \mathrm{~mm}$ 上にコロナ放電線を取り付け， $-5,400 \mathrm{~V}$, コロナ電流約 $4.2 \times 10^{-5} \mathrm{~A}$ の条件下で帯電させ, 表面の 带電位の变化を表面電位計にて測定した。光照射はタン グステン球にて $2001 \mathrm{x}$ の白色光を用いた。コロナ帯電 特性はコロナ放電を 1 分間行ない，そこから暗隇衰させ た。光減衰は 1 分間の暗減衰時ののちに光を速続して照 射して，その電位減衰を測定した。な呿温度は $20^{\circ} \sim 40$ ${ }^{\circ} \mathrm{C}$ の範囲で変化させ，相対湿度は $30 \%$ 飞保った。

\section{4. 結果}

図-3 には $\mathrm{ZnO} 60 \mathrm{wt} \%, \mathrm{PVAc} 40 \mathrm{wt} \%$ のセンサー 飞特ける温度をパラメータとしたときの暗減衰を $\log V_{d}$ と $\sqrt{t}$ でプロットした例を示す。初期減衰を除けばいず れもよい直線性を示し, 直線の傾斜は温度の高いものほ そ大をい。

図-4 には $\mathrm{TiO}_{2} 30 \mathrm{wt} \%$, PVAc $70 \mathrm{wt} \%$ のセンサー に持ける温度をパラメータとしたときの瞕減衰を同じく $\log V_{d}$ と $\sqrt{t}$ のプロット纪表わした。これからわかるよ ら飞 $\mathrm{TiO}_{2}$ センサーに打いても $\mathrm{ZnO}$ と同様に $\log V_{d}$ と $\sqrt{t}$ は直線的になり, その直線の傾斜は温度の高いもの

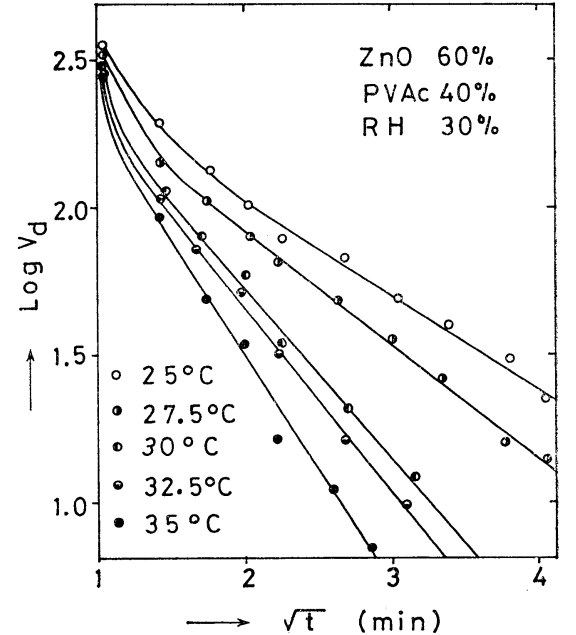

図-3 $\mathrm{ZnO}$ 分散壃でのコロナ電位の減衰特性 の温度変化

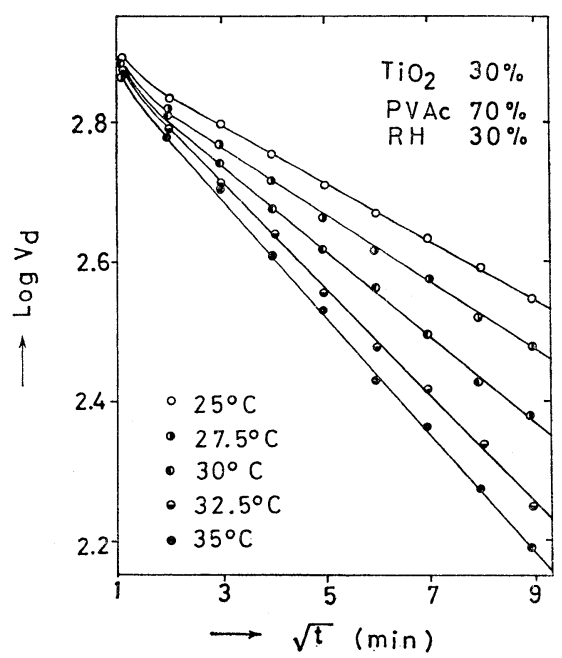

図-4 $\mathrm{TiO}_{2}$ 分散層でのコロナ電位の減衰特性の 温度変化

ほど大きい。

図-5には上記の直線の傾斜が絶対温度の平方根に比 例して変化していることを示した。ZnO に和いて，そ の混合重量を $0 ， 30 ， 60 ， 75 \%$ と変化させても，この関 係は成り立って物り，特に $\mathrm{ZnO}$ が $0 \%$ の高分子だけの センサーに扔いてもこのことがいえる。

この関係は $\mathrm{TiO}_{2}$ 分散層に敊いても全く同様なことが 成立し, ZnO の場合と傾向がよく似ている。

図-6 には ZnO 60wt\%，PVAc 40wt\% のセンサー の光減衰の電位変化を $\log V_{p h}$ と $\sqrt{t}$ についてプロット した。この場合は現象が速いので，必ずしもよい直線性 を示していないが，近似的に直線を引くことができる。 


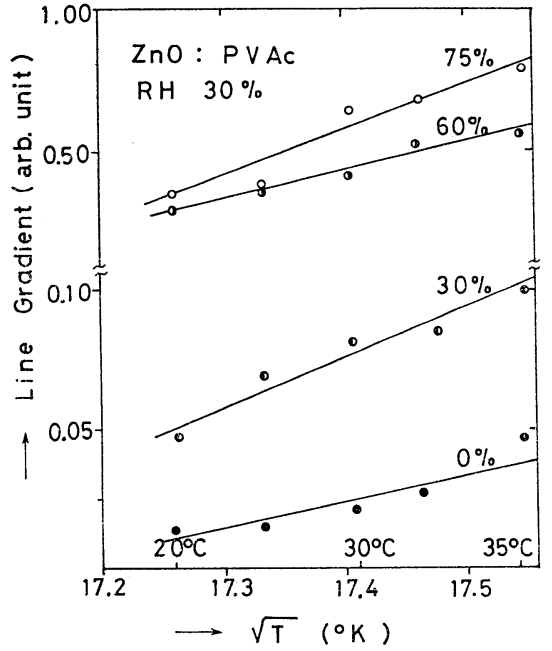

図-5 $\log V_{d}$ と $\sqrt{t}$ の直線性のこう配と絶対温 度の平方根の関係

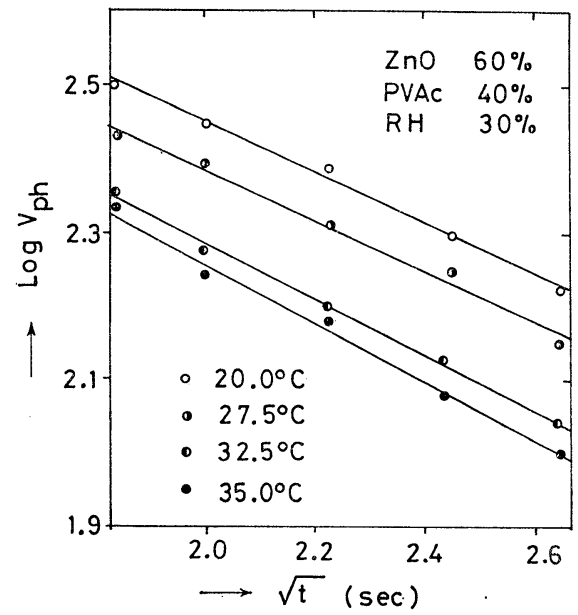

図-6 $\mathrm{ZnO}$ 分散層に拉ける光減衰の $\log V_{p h}$ と $\sqrt{t}$ の関係

$\mathrm{ZnO}$ が $60 \mathrm{wt} \%$ も入ると, 光感度が非常に大きくなり, 暗減衰でみられたような温度効果が現われていない。

図-7 には $\mathrm{TiO}_{2} 10 \mathrm{wt} \%$, PVAc $90 \mathrm{wt} \%$ にはの光減 衰に频ける $\log V_{p h}$ と $\sqrt{t}$ との関係を示す。この場合は $\mathrm{TiO}_{2}$ が 10wt\%しか入っていないので, 光感度はさほど 大きくなく, 温度效果が現われている。暗減衰の場合と 同様に光減衰の場合にも温度の高いものほど減衰が速い。

\section{5. 考 察}

井上らによって実験式として与えられているコロナ帯 電の暗減衰の式はこの研究に执いても十分に成立してい ることが示され，さらにその減衰の速度が温度に依存し

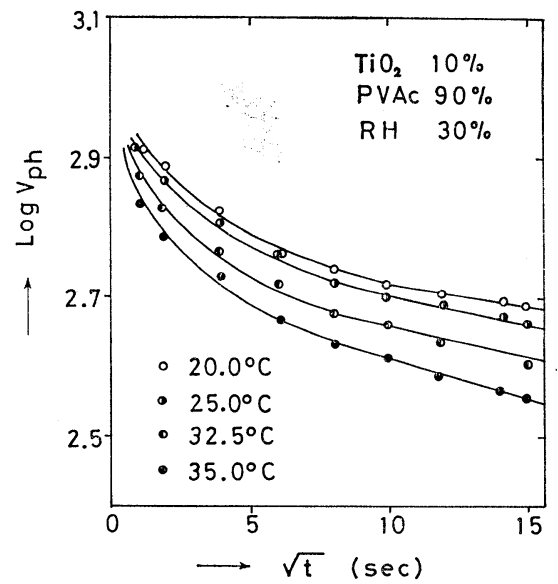

図-7 $\mathrm{TiO}_{2}$ 分散層に拈ける光減衰の $\log V_{p h}$ と $\sqrt{t}$ の関係

て和り, 温度の高いものほど減衰が速く, 絶対温度の平 方根を横軸にとって，そのこう配をプロットしてみると ほぼ直線的関係が得られることがわかった。

井上らは $\log V$ が $\sqrt{t}$ に比例する関係はあくまで経 験的なるのであり，ある電圧の範囲での近似にすぎない と説明している。だから本質的にはセンサーのRと Cが 空間電荷の蓄積，あるいはその他の効果によって時間的 に変化することによって説明されるべきであるとし，近 似のない場合は

$$
V=\Sigma_{i} V_{i} e^{-\frac{t}{\tau_{i}}}
$$

のよらなそれぞれの $V_{i}$ に和ける時定数 $\tau_{i}$ を算出すべ きであるとしている2)。さらにはセンサーの電位減衰の 温度依存性は $\mathrm{ZnO}$ や $\mathrm{TiO}_{2}$ の表面化な吸着種の熱平衡 よりのずれによる物性変化によるとしている。

ところがわれわれのモデルは時間の平方根に依存して 電位が減衰するのは層中をコロナイオンが拡散してゆく ことによるというものである。そこで輸送理論の式を使 って電位の時間変化を示す微分方程式を導さ，との非線 型項を小さいと近似して解を得た。その結果，井上らの 実験式とほぼ同形式の理論式を得ることができた。その 解の係数には桩散定数と絶対温度とセンサーの厚さの変 数が含まれていた。そこで実験によってこのモデルの正 当性を調べるには温度変化させて電位減衰をとり，その こう配が絶対温度の平方根に比例することを示す必要が あった。その結果は図-5 に示すようにかなりよい直線 関係を得ている。よってこのモデルと非線型項を落した といら近似はある程度正しいと考兄られ。しかしこれ を即座に正しいと結論することは危険である。なぜなら 非線型項は静電ポテンシャルによるコロナイオンの流れ 
からくる項でセンサーの中では濃度ポテンシャルと同程 度ぐらいにきいてくる項であると思われる。このあたり はもっと電位の低いところでの測定を多くやって, この 項を小さくしていったときの減衰特性を十分に検討しな ければならない。さらにこの項が小さいとして無視でき ない場合はさらに数值解析法によって実際に非線型項を 含んだ形で微分方程式を解いていかねばならないだろ 5 。

さらに実験上の問題点としては図-5 に示すように直 線の傾斜が絶対温度の平方根に比例するといら有力な手 掛かりも，これらの実験だけでは $20 \sim 35^{\circ} \mathrm{C}$ と範囲が狭 く, 理論の正当性を実証するといら結論はだせない段階 にある。これらは今後液体窒素を使った実験をやって低 温での電位減衰を測定する必要があろら。これらが今後 に残された問題点である。

電荷をもったイオンが層中を動いて裏面に達してどの よらにして電荷をわたして消失するかといら問題はこの 場合にさほど大きな困難なしに説明できる。それはセン サーの中には多くの空吵があり, 空気層が多く含まれて いるので電荷を放出したイオンはそれらの空隙へ出てい

\section{くと考えることができる。}

光減衰の場合にも図-6, -7 に示したよらに暗減衰と 同じような傾向が現われた。これは次のように説明でき よう。光が照射した場合には $\mathrm{ZnO}$ や $\mathrm{TiO}_{2}$ の表面に電 子-正孔対が生じ, 正孔がトラップ化される。この正孔 はコロナイオンの電荷を中和する力をもっているので, コロナイオンは裏面まで達する必要がなく $\mathrm{TiO}_{2}$ や $\mathrm{ZnO}$ の表面にて中和されてしまら。コロナイオンが層中を拡 散することは暗減衰の場合と同様であるが，その拡散の 距離が非常に短くなり, 減衰が急速に進行すると考えら れる。

これらの実験を渡部達矢, 石井寛, 野中豊一の各氏に 協力いただいた。ここで感謝する。

(日本化学会第 24 年会 B 講演発表)

$$
\text { 文献 }
$$

1) J.A.Amick, RCA Rev., 770 (1959)

2) 井上英一, 小門宏, 山口隆志, 永島伸一郎, 高橋 賢次，電子写真，Vol.1，27 (1959)

3）飯田武揚, 野崎弘, 電子写真学会予稿, No. 25 (1970)

\section{新刊紹介}

カーボンブラック便覧カーボンブラック協会編

図書出版社 A5 判 520 頁 4000 円

本書はカーボンブラック協会 20 周年記念として刊行 されたものである。旧版「便覧カーボンブラック」は昭 和 25 年に発刊されたが, 戦後間もない時期であり我が 国のカーボンブラック工業は極めて微弱な時代であり, また当時, カーボンの科学も未だ極めて未開であった。 旧版の序に和いて, 故田中芳雄先生はカーボンブラック の補強剤としての有用性と重要性を述べられたあとで, 「カーボンブラックの本質に関する科学的研究にはな拉 多くの余地が残されて拉り, カーボンブラック粒子の表 面活性の本質, あるいはゴムに対する増強, またはその他 の効果の理論に関しては多くはな敃暗中模索の状態であ る」と述べられている。その後 20 年, 我が国のカーボン ブラック生産量は当時の 100 倍に達し生産量は世界で第 3 位の地位を占めている。またカーボンの科学もまた急 速に進展し, カーボンの構造・性質も非常に明らかにな り,さらに近時新しいカーボン系工業材料も多数開発さ れて来た。このような背景をもとにして刊行された本便 覽の内容は旧版に比べると名実ともに隔世の感がある。

本書は全 520 ページ, 内容は, I：総括編, II : 商業 編, III : 製造編, $\mathrm{N}$ : 基礎編, $\mathrm{V}$ : 応用編, $\mathrm{V}$ : 資料編 の 6 編に分れている。全体を通して現在に和けるカーボ
ンブラック工業の実態とカーボンブラックの応用括よび カーボン科学の現状について詳しく述べられている。と

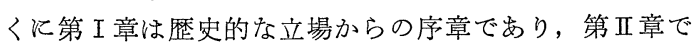
は世界に括ける概況, カーボンブラックの各種の分類, 各国の事情, 日本の現状と将来の展望などが記されてい る。第亚章では, 製造法の詳細が示され, 工場衛生と防 災, 公害の問題にまで言及している。第 $\mathbb{N}$ 章ではカーボ ン類の一員であるカーボンブラックの基礎的諸特性が詳 細に述べられている。炭素の結晶構造から始まって, 粒 子構造, 表面構造, 各種の性質, 生成機構, ゴム補強性 について示されているが, 文献の引用も極めて豊富であ り,この部分のみでも一冊の成書となる価值を有してい る。第 $\mathrm{V}$ 章はゴム, プラスチック, 印刷インキ, 塗料, 乾電池, 炭素製品, 墨その他に対する応用を中心として 示されている。カーボンブラックの分散の問題, ゴムに おける機械的性質の問題などについて多くの引用例を示 し, また各種添加剤を含めた極めて数多くの配合例が示 されている。第И章は主として法規, 規格, 市販品の銘 柄と特性值, 試験法叔よびカーボンブラックの製造・応 用についての特許を網らしている。

以上述べたように，本書はカーボンブラックを商業， 製造, 基礎, 応用の側からとらえた他に余り類を見ない 成書といえるし，またカーボンブラックに関心をるつ利 用者, 技術者, 研究者, 生産者に広く役立つことが期待 される。

（高橋 浩） 